The Yale Library of Military History

Donald Kagan and Frederick Kagan, Series Editors 
This page intentionally left blank 


\title{
THE ETHIOPIAN
} REVOLUTION

\section{War in the Horn of Africa}

\author{
Gebru Tareke \\ Foreword by Donald Kagan \\ and Frederick Kagan
}

Yale University Press

New Haven E London 
Copyright $\odot 2009$ by Yale University. All rights reserved.

This book may not be reproduced, in whole or in part, including

illustrations, in any form (beyond that copying permitted by Sections 107 and 108 of the U.S. Copyright Law and except by reviewers for the public press), without written permission from the publishers.

Designed by Nancy Ovedovitz.

Set in Electra and Trajan types by Tseng Information Systems, Inc..

Printed in the United States of America.

Library of Congress Cataloging-in-Publication Data

Gebru Tareke, 1940-

The Ethiopian revolution : war in the Horn of Africa / Gebru Tareke ; foreword by Donald Kagan and Frederick Kagan.

p. cm. - (Yale library of military history)

Includes bibliographical references and index.

ISBN 978-0-300-14163-4 (hardcover : alk. paper) 1. Ethiopia-History-1974-

2. Eritrea-History-Revolution, 1962-1993. 3. Eritrean-Ethiopian War, 1998-

4. Somali-Ethiopian Conflict, 1977-1979. 5. Somali-Ethiopian Conflict, 1979- I. Title.

$$
\begin{gathered}
\text { DT387.95.G43 } 2009 \\
963.07-\mathrm{dc} 22 \\
2008044346
\end{gathered}
$$

A catalogue record for this book is available from the British Library.

This paper meets the requirements of ANSI/NISO Z39.48-1992 (Permanence of Paper).

It contains 30 percent postconsumer waste $(\mathrm{PCW})$ and is certified

by the Forest Stewardship Council (FSC). 
In memory of my parents

Widisti Menkir

Tareke Mengesha

And

All those who died for a free, democratic, and secular Ethiopia 
This page intentionally left blank 